\title{
Keskustelua
}

\section{PARI RAJAUSTA - KOMMENTTI OLLI PERHEENTUVALLE}

kuinka tutkijan vastuu lopultakin kehittyy.

Olli Haapalan teos on pieni, mutta ansiokas. Se tuo keskustelun kohteeksi selkeästi perustellen monia ongelmia, jotka ovat uuden biologian seurauksia. Vastauksista voidaan väitellä, mutta vielä tärkeämpää olisi, että uudet kysymykset nähtäisiin nykyistä kirkkaammin.

Olli Järvinen
$T \& E: n$ edellisessä numerossa Olli Perheentupa kommentoi artikkeliani Marxismin rajalle! $(T \& E$ 1/86). Pidin kommenttia kiinnostavana, vaikkakaan en hermeneuttisen otteen läpitunkemana. Siksi pari vastakommenttia.

Artikkelissani oli kolme osaa. Ensimmäisessä osassa kävin hyvin yleisellä tasolla läpi kuusi ongelmakohtaa, jotka on osoitettu erilaisista marxismeista erilaisissa keskusteluissa. En halunnut mennä näihin keskusteluihin sisälle, koska artikkelista muutoin helposti olisi paisunut kirjan mittainen. Kaikki kommentit eivät osuneet kaikkiin marxismeihin ja joihinkin marxismeihin ei osunut mikään niistä. Niitä yhdisti kuitenkin se, että ne kaikki parhaiten sattuivat sellaisiin marxismeihin, jotka ovat pyrkineet rakentamaan kattavan yhteiskuntateorian tai kriittisen teorian pohjautuen nimenomaan Marxin teksteihin. Esittämäni ongelmakohdat osoittavat käsittääkseni, ettei tällainen projekti ole mielekäs.

Artikkelin toisessa osassa oli tarkoitus relativoida kriittiseksi yhteiskuntateoriaksi tulkittu Marxin ekonomiakriittinen esitys. Ideana oli, että Marxin teoria ei voi olla koko kriittinen yhteiskuntateoria eikä antaa kaikkia tällaisen teorian käsitteitä. Silti ekonomiakritiikki - tavalla tai toisella tulkittuna - on otettava elementiksi kriittisen yhteiskuntateorian kehittelyihin. Ekonomiakritiikin relativoimiseksi ryöstöviljelin Foucault'ta.

Artikkelin kolmannessa osassa ihmeteltiin sitä mitä kriittinen teoria sitten oikein voi olla. Esitin siinä kannan, jonka mukaan ei ole syytä fiksautua kiinni yhteen kriittisen teorian muotoon, vaan kriittinen teoria olisi nähtävä liikkeenä frankfurtilaisen epookin teorian ja ranskalaisen dekonstruktionismin välillä.

Yritin siis artikkelissani etsiä kriittisen yhteiskuntateorian määreitä nykyisessä teoreettisessa tilanteessa. Sitä varten pyrin siivoamaan tieltä eräitä marxilaisen perinteen jättämiä pahimpia sotkuja.

Perheentuvan kommentti ei puhu tällaisista asioista mitaän. Perheentuvan perusidea on, että Marxin ekonomiakritiikkiä olisi luettava $\mathrm{Ri}$ - cardon teorian kritiikkinä ja ekonomiakritiikin pätevyysalue olisi myöskin määritettävä tästä lähtien. Hän ennakoi tällaisen tulkinnan tuloksia ja testaa tulkintaa artikkelissani esitettyihin marxismin ongelmakohtiin. Ei ole varsinainen yllätys, että tulkinta kestää.

Perheentuvan perusidea on mielestäni hedelmällinen. Marxin tulkinta Ricardon teorian kriitikkona tuottaa varmasti kiinnostavia tuloksia - kuten on tuottanut Marxin tulkinta Hegelin ideamystiikan kriitikkona (Hänninen 1981, 17-162) ja Marxin tulkinta sen luonnonoikeudellisen kapitalismin legitimaatiotavan kriitikkona, jonka Marx attribuoi Lockelle ja Smithille (Gronow 1986, 165-225). Samalla se täydentää kuvaamme 'kypsästä Marxista". Puuttumaan jäả oikeastaan enää vain Marxin tulkinta utopistisosialismin kriitikkona. Tällaiset tulkinnat ovat aina tarkkoja teoriakriittisiä tutkimuksia, joihin ryhdyttäessä on jo ennalta selvää, että tarkasteltavana oleva teoria ei tematisoi koko yhteiskunnallista todellisuutta vaan esittää erään tai eräiden yhteiskunnallisesti merkittävien teoreettisten fiksaatioiden (tai ajatusmuotojen, jos niin halutaan) kritiikin. Ne eivät pyrikään tekemään marxismista "johtotiedettä" tai kattavaa yhteiskuntateoriaa - ja siksi juuri ne ovat Marx-tulkintoja, jotka edelleen kiinnostavat myös niitä kriittisiä teoreetikoita, jotka nykyisin pääasiassa liikkuvat alueilla, joille marxilainen käsitteistö ei yllä.

Kommenteissaan Perheentupa ei vielä eksplikoi omaa Marx-tulkintaansa kovinkaan pitkälle. Tällainen eksplikointi näyttäisi kuitenkin olevan sellaisen Marx-keskustelun ehto, jossa keskustelijat eivät puhuisi toistensa ohi. Jään siis kiinnostuneena odottamaan.

Risto Heiskala 


\section{Tieteellinen elämä}

\section{Kirjallisuus}

Gronow, Jukka (1986): On the Formation of Marxism. Karl Kautsky's Theory of Capitalism, the Marxism of Second International and Karl Marx's Critique of Political Economy. Commentationes Scientarium Socialium 33. Finnish Society of Sciences and Letters. Helsinki.

Heiskala, Risto (1986): Marxismin rajalle! Tiede \& Edistys vol. 11, 1986:1.

Hänninen, Sakari (1981): Aika, paikka, politiikka. Marxilaisen valtioteorian konstituutiosta ja metodista. Tutkijaliiton julkaisusarja 17. Kirjapaino-osakeyhtiö Kaleva. Oulu.

Perheentupa, Olli (1986): Rajat "marxismille"! - kommentteja Risto Heiskalalle. Tiede \& Edistys vol. 11. 1986:3.
INTERNATIONALE Gesellschaft für Dialektische Philosophie, Societas Hegeliana eli se Hegel-seura, jonka ansiokkaana primus motorina Suomessa toimii professori Juha Manninen, järjestää 3.-7. toukokuuta 1988 Pariisissa suuren kansainvälisen kongressin Ranskan vallankumouksen 200-vuotispäivien merkeissä. Kongressiin lasketaan saapuvan 350 osanottajaa. Kongressin keskeiset esitelmät tullaan julkaisemaan seuran toimesta 1989. Tämän suurtapahtuman teemoihin kuuluvat alustavasti kutsukirjeen mukaan:

- Natur, Entwicklung, Geschichte, Fortschritt, Erkenntnis, Sprache, Wissenschaft, Philosophie, Recht, Staat, Politik . . .

- Rousseau, Encyclopédie, Traditionen des Rationalismus, Materialismus, Sensualismus, klassische deutsche Philosophie, Destutt de Tracy, Cabanis, Idéologie, Saint-Simon, Fourier, Babeuf, wissenschaftliche Institutionen, Einfluss der Ideen der französischen Revolution in anderen Ländern, Philosophie und Wissenschaften . . . . .

Kiinnostuneiden on syytä ottaa pikainen yhteys prof. Juha Manniseen Oulun yliopiston historian laitokselle.

PROFESSORI, Tilastokeskuksen pääjohtaja, O. E. Niitamo täytti 23.11.1986 60 vuotta. Niitamo on yksi 60- ja 70-lukujen suuria keskustelijoita, monipuolinen talousja tilastomies, joka ensimmäisenä Suomessa laskeskeli koulutuksen osuutta tuottavuuden kasvusta ja sittemmin puuhaili niin hyvinvoinnin kuin sosiaali-indikaattoreiden kuin tulevaisuudentutkimuksenkin kanssa. Niitamon jutut olivat usein ns. revolverijuttuja, nopeasti tehtyjä, täynnä ideoita, usein melkeinpä pelkästään ranskalaisia viivoja. Mutta samanlainen on mies itsekin, aina ideoita ja tarinoita hersyvä.

Helsingin yliopisto menetti Niitamossa loistavan opettajan, jonka puute näkyy taloustieteellisen tutkimuksen pahanlaisena umpioitumisena ja yhteyksien puutteena. Toisaalta Tilastokeskus, melkoisen jäykkä valtion virasto, saa olla tyytyväinen siitä, että sillä on Niitamon kaltainen epämuodollinen "teknokraatti" johtajanaan.

Nykyisin yhä enemmän yleistyneen tavan mukaan myös Olli Niitamo on saanut syntymäpäivänsä kunniaksi juhlakirjan, Taulukoinnista tietoyhteiskuntaan, jossa kirjoittajina on joukko kotimaisia ja ulkomaisia tilasto- ja talousmiehiä. Kirja onkin niin kuivakan arvovaltainen, ettei se ehkä aivan täysin vastaa Niitamon kokovartalokuvaa tutkijana. Kuulemma yksi kirjan kirjoittajista - tunnettu elämäntapatutkija - olikin tarjonnut ranskankielistä kirjoitusta kirjaan (Ollin ranskankielentaitohan on tunnettu), mutta toimituskunta oli sen hylännyt. Mikäli huhu pitää paikkansa, niin tapaus on valitettava: juuri sellaisia väriläiskiä Olli on itsekin aina toiminnassaan suosinut.

Tiede \& Edistys onnittelee päivänsankaria lämpimästi ja toivoo voivansa vielä joskus julkaista hänen revolverijuttujaan.

ALBRECHT WELLMER piti kesäkuun alussa Jyväskylässä iltapäiväseminaarin modernista ja postmodernista. Tämä konstanzilainen, tätä nykyä New School of Social Researchissa opettava filosofi on hiljattain julkaissut teokset Zur Dialektik von Moderne und Postmoderne ja Ethik und Dialog, jotka jo kertovat hänen "rationaalisesta" ja "järkevästä" postmodernismistaan. Muuttuiko postmodernismi siis kiveksi kun Wellmer tarttui siihen? Ei sentään. Postmoderni ei Wellmerille ole elämänasenne, joka vapauttaa meidät huolenkantamisesta, se ei ole pettymyksistä ja angsteista vapauttava liike, se ei houkuttele meitä vapautumaan kompleksisesta maailmasta eikä se lupaa vapautusta itsestämme. Seminaarissa kävi selvästi ilmi että postmoderni on Wellmerille "vain" siirtymävaiheen konstellaatio, joka panee meidät reflektoimaan modernia tietoisuutta, ihmiskulttuurin historisiteettia, totalisoivaa teknistä rationaliteettia, "second modernityä" eli lyhyesti rationaliteetin statuksen muutosta. Kenelle "rationaalinen" ja "järkevä" keskustelu postmodernismista on "mielekästä", kenelle se on on- 